\title{
EFEKTIVITAS PENGGUNAAN MEDIA FLIPCHART DAN KOMIK DALAM PENDIDIKAN KESEHATAN TERHADAP PENGETAHUAN MENGGOSOK GIGI PADA SISWA SDI RADEN PAKU SURABAYA
}

\author{
Nabila Debrin ${ }^{1}$, Endang Purwaningsih ${ }^{2}$, Soesilaningtyas ${ }^{3}$ \\ ${ }^{123}$ Jurusan Keperawatan Gigi Politeknik Kesehatan Kementerian Kesehatan Surabaya \\ Email : nabiladebrin@gmail.com
}

\begin{tabular}{ll}
\hline & ABSTRAK \\
\hline Kata Kunci : & Kesehatan gigi di SDI Raden Paku Surabaya mengalami angka \\
Pendidikan Kesehatan Gigi, & karies atau sebesar 86,7\%, dan sebanyak 4 siswa atau sebesar 13,33\% \\
Media Flipchart, Komik. & tidak mengalami karies. Tujuan penelitian mengetahui efektivitas \\
& media flipchart dan media komik dalam pendidikan kesehatan \\
& tentang pengetahuan menggosok gigi siswa kelas 2 di SDI Raden \\
& Paku Surabaya. Metode penelitian, jenis penelitian yang dilakukan \\
& adalah penelitian Quasi experiment. Penelitian ini menggunakan \\
& rancangan two Group Pretest Postest dan menggunakan teknik simple \\
& random sampling atau acak. Pengumpulan data menggunakan \\
& kuesioner. Responden penelitian siswa kelas 2 SDI Raden Paku \\
& sebanyak 48 siswa. Hasil penelitian penggunaan media flipchart dan \\
& komik dalam pendidikan kesehatan terhadap pengetahuan \\
& menggosok gigi dapat meningkatkan pengetahuan siswa. \\
Kesimpulan tidak ada perbedaan efektifitas penggunaan media & fliphart dan komik dalam pendidikan kesehatan terhadap \\
pengetahuan menggosok gigi pada siswa SDI Raden Paku Surabaya.
\end{tabular}

Key word:

Dental Health Education, Flipchart Media, Comics

\begin{abstract}
ABSTRCT
Introduction: Dental health at SDI Raden Paku Surabaya experiences low caries-free rates. Grade 2 students, 26 students experienced caries or $86.7 \%$, and as many as 4 students or $13.33 \%$ did not have caries. Objective: The objective research is to find out the effectiveness of flipchart media and comic media in health education about knowledge brushing teeth of grade 2 students at SDI Raden Paku Surabaya. Method: The research method, the type of research conducted is research Quasi experiment. This study uses two Group Pretest Postest designs and uses simple random sampling techniques. Data collection using questionnaire. The research respondents of the second grade students of SDI Raden Paku were 48 students. Results: The results of research on the use of flipchart media and comics in health education on the knowledge of brushing teeth can improve student knowledge. Conclusion: Conclusion there is no difference in effectiveness the use of flipchart media and comics in health education on the knowledge of brushing teeth on students SDI Raden Paku Surabaya.
\end{abstract}

\section{PENDAHULUAN}

Kesehatan adalah keadaan sehat, baik secara fisik, mental, spriritual maupun sosial yang memungkinkan setiap orang untuk hidup produktif secara sosal dan ekonomis (UU RI NO 36 tahun 2009). Kesehatan rongga mulut harus terjaga karena rongga mulut merupakan suatu tempat yang amat ideal bagi perkembangan bakteri, karena 
temperatur, kelembapan dan awal makanan di cerna mulai makanan tersebut dimasukkan kedalam rongga mulut.

Hasil riskesdas menunjukan bahwa 54,0\% anak usia sekolah mengalami karies. Anak usia sekolah yang mempunyai masalah gigi dan mulut sebanyak $67,3 \%$, sedangkan anak usia sekolah yang sudah dilakukan perawatan sebanyak 14,6\%. Hasil tersebut menunjukkan bahwa kurangnya pelayanan kesehatan gigi dan mulut bagi masyarakat (RISKESDAS 2018).

Penelitian ini ditujukan kepada siswa dan kelas 2A dan 2B di SDI Raden Paku Surabaya tentang cara menggosok gigi dengan tepat dan waktu yang benar, karena Sebanyak 86,67\% siswa mengalami karies sedangkan sebanyak 13,33\% bebas karies gigi. Media yang akan digunakan adalah media flipchart dan media komik. Media adalah alat yang menyampaikan atau mengantarkan pesan pesan pembelajaran (Arsyad, 2011). Media flipchart atau lembar balik adalah media menyampaikan pesan atau informasi kesehatan dalam bentuk lembar balik. Media komik adalah salah satu media cetak yang mudah digunakan, relatif murah, awet, dan fleksibel (Marisa dan Nuryanto, 2014 cit Mardiana 2019). Penentuan media yang akan digunakan harus disesuaikan dengan siswa. Penentuan media yang tidak tepat dapat mengakibatkan informasi yang akan disampaikan kepada peserta tidak tersampaikan. Perluasan konsep tentang media, dimana teknologi bukan sekedar benda, alat, bahan atau perkakas, tetapi tersimpul dengan sikap, perbuatan, organisasi dan menejemen yang berhubungan dengan penerapan ilmu (Achsin, 1986, cit Arsyad, 2011).

Tujuan dari penelitian ini mengetahui efektivitas media flipchart dan media komik dalam pendidikan kesehatan tentang pengetahuan menggosok gigi siswa kelas 2 di SDI Raden Paku Surabaya.

\section{METODE}

Jenis penelian ini adalah Quasi experiment. Penelitian ini menggunakan rancangan two group pretest postest, yang dilakuan pada siswa kelas 2 di SDI Raden Paku Surabaya. Metode pengumpulan data menggunakan kuesioner untuk mengukur pengetahuan menggosok gigi siswa kelas 2 Sekolah Dasar Islam Raden Paku Surabaya. Peneliti memberikan permainan undian kertas untuk menentukan responden media flipchart dan komik. Responden dalam penelitian ini adalah siswa SDI Raden Paku Surabaya, siswa kelas 2 sejumlah 48 siswa. Data yang diambil pada bulan Desember-Maret 2020 merupakan jawaban dari responden tentang pengetahuan menggosok gigi.

\section{HASIL DAN PEMBAHASAN}

Tabel 1. Hasil perhitungan rata-rata pengetahuan menggosok gigi pada SDI Raden Paku Surabaya Kelas 2

\begin{tabular}{ccc}
\hline Media & Tindakan & Nilai Rata-Rata \\
\hline Flipchart & Sebelum & 50 \\
& Sesudah & 91 \\
Komik & Sebelum & 42 \\
& Sesudah & 88 \\
\hline
\end{tabular}


Berdasarkan tabel 1, bahwa media flipchart dan komik dapat meningkatkan pengetahuan menggosok gigi pada siswa.

Tabel 2 : Hasil uji shapiro - wilk terhadap media flipchart dan komik pada SDI Raden Paku Surabaya Kelas 2

\begin{tabular}{ccc}
\hline Media & Responden & Nilai Sig \\
\hline Flipchart & 24 &, 004 \\
Komik & &, 001
\end{tabular}

Berdasarkan tabel 2 hasil uji shapiro - wilk media flipchart dan komik dengan responden 24 siswa, dengan sig kurang dari 0,05 maka data tersebut dapat dikatan tidak nomal.

Tabel 3 hasil uji wilcoxon terhadap media flipchart dan komik komik pada SDI Raden Paku Surabaya Kelas 2

\begin{tabular}{ccc}
\hline Media & Responden & Nilai Sig \\
\hline Flipchart & 24 & 0,000 \\
Komik & & 0,000 \\
\hline
\end{tabular}

Berdasarkan tabel 3 terdapat media flipchart dan komik dengan nilai sebesar 0,000 atau kurang dari 0,05. Data tersebut dapat dikatakan normal.

Tabel 4 hasil uji mann whitney menggunakan media flipchart dan komik pada SDI Raden Paku Surabaya Kelas 2

\begin{tabular}{ccc}
\hline Media & Nilai Rata Rata & Nilai Sig \\
\hline Flipchart & 91 & 0,368 \\
Komik & 88 & 0, \\
\hline
\end{tabular}

Berdasarkan tabel 4 terdapat nilai sig 0,368 atau lebih dari 0,05 maka dapat disimpulkan bahwa tidak ada perbedaan efektivitas pendidikan kesehatan dengan media flipchart dan komik.

\section{PEMBAHASAN}

\section{Hasil Pendidikan Kesehatan Terhadap Pengetahuan Menggosok Gigi Menggunakan Media Flipchart}

Hasil analisa data menunjukkan, siswa kelompok media flipchart memiliki pengetahuan tentang waktu mengganti sikat gigi termasuk dalam kategori kurang atau rendah. Pengetahuan menggosok gigi siswa kelas 2 SDI Raden Paku Surabaya Tahun 2020 termasuk dalam kategori baik. Hal ini dipengaruhi pendidikan kesehatan terhadap pengetahuan menggosok gigi dengan menggunakan media flipchart. Hal ini dipengaruhi banyak indera yang dapat digunakan siswa, sehingga siswa dapat memperhatikan peneliti dalam menyampaikan pendidikan kesehatan terhadap pengetahuan menggosok gigi siswa SDI Raden Paku Surabaya. Bagaray (2016) cit Sitanaya (2019) berpendapat dalam penelitiannya bahwa penangkapan pengetahuan 
yang diberikan melalui media flipchart memanfaatkan lebih dari satu indera yaitu indera penglihatan dan pendengaran (indera pendengaran sebesar $13 \%$ dan indera penglihatan 75\%-87\%). semakin banyak indera yang dilibatkan dalam pemberian informasi, maka semakin mudah pesan tersebut dapat diterima dan dipahami dengan baik.

\section{Hasil Pendidikan Kesehatan Terhadap Pengetahuan Menggosok Gigi Menggunakan Media Komik}

Hasil analisa data menunjukkan, siswa kelompok media komik memiliki pengetahuan tentang cara menggosok gigi yang menghadap bawah lidah termasuk kategori sedang. Pengetahuan menggosok gigi siswa kelas 2 SDI Raden Paku Surabaya Tahun 2020 termasuk dalam kategori baik. Hal ini dipengaruhi siswa pada kelas 2 menyukai buku gambar, karena pada buku gambar terdapat kartun yang mereka suka dan buku gambar tersebut memiliki warna yang berbeda beda. Menurut Notoatmodjo, 2007 cit Ida Chairanna Mahirawatie, 2015 Ketika anak diberi informasi melalui media komik, maka yang timbul adalah kesadaran. Setelah anak sadar akan pentingnya perawatan kesehatan gigi maka tahapan selanjutnya adalah ketertarikan. Pada tahap ini anak sadar terhadap stimulus berupa pengetahuan tentang kesehatan gigi. Kemudian pada tahap ini pula anak sudah mulai melakukan suatu tindakan. kemudian anak melewati tahap evaluasl yaitu memikirkan baik buruk stimulus yang ia terima setelah adanya sikap ketertarikan. Apabila stimulus yang dianggap buruk/kurang terkesan, maka ia akan diam/acuh. Sebaiknya apabila stimulus yang ia terima dianggap baik ia akan membuat seseorang melakukan suatu tindakan.

Pengetahuan menggosok gigi siswa kelas 2 SDI Raden Paku Surabaya Tahun 2020 termasuk dalam kategori baik. Hal ini dipengaruhi pendidikan kesehatan terhadap pengetahuan menggosok gigi dengan menggunakan media komik. Media komik edukasi merupakan salah satu media pengajaran yang dapat digunakan untuk menyampaikan bahan ajar pada anak, dengan gambar yang menarik perhatian anak akan tertuju langsung sehingga mampu merangsang partisipasi aktif para siswa, membangkitkan motivasi belajar siswa, mengatasi keterbatasan ruang dan waktu, dapat menyajikan laporan-laporan yang actual dan orisinil yang sulit dengan menggunakan media lain, menyajikan pesan dan informasi secara serempak bagi seluruh siswa, dan mampu mengembangkan daya imajinasi (Putriani, 2016 cit Trilia, 2020).

\section{Hasil Pendidikan Kesehatan Terhadap Pengetahuan Menggosok Gigi Menggunakan Media Flipchart Dan Komik}

Hasil analisa data menunjukkan, pengetahuan menggosok gigi siswa kelas 2 SDI Raden Paku Surabaya Tahun 2020 termasuk dalam kategori baik. Pendidikan kesehatan terhadap pengetahuan menggosok gigi menggunakan media flipchart dan komik dapat meningkatkan pengetahuan siswa. Hal ini di pengaruhi siswa kelas 2 tertarik untuk mendengarkan cerita dan tertarik pada buku bergambar yang terdapat kartun dan terdapat warna warni pada buku bergambar. Hasil dari media flipchart dan komik dapat meningkatkan pengetahuan, tetapi berdasarkan analisis data tidak ada perbedaan dalam pendidikan kesehatan terhadap pengetahuan menggosok gigi siswa kelas 2 SDI Raden Paku Surabaya. 
Menurut Edgar Dale yang digambarkan lewat 'Kerucut Pengalaman Dale,' proses pendidikan dengan melibat-kan lebih banyak indera akan lebih mudah diterima dan diingat oleh para sasaran pendidikan. Pemberian pendidikan kesehatan pun akan lebih efektif dan hasilnya optimal ketika menggunakan metode dan media pendidikan kesehatan yang tepat dan melibatkan lebih banyak indera ( Kantohe, Wowor, Gunawan 2016).

\section{KESIMPULAN}

SIMPULAN

Berdasarkan analisis data maka dapat disimpulkan :

1. Pendidikan kesehatan menggunakan media flipchart dapat Meningkatkan pengetahuan menggosok gigi siswa SDI Raden Paku Surabaya.

2. Pendidikan kesehatan dengan menggunakan media komik dapat meningkatkan pengetahuan menggosok gigi siswa SDI Raden Paku Surabaya.

3. Efektifitas Penggunaan media flipchart dan komik dalam pendidikan kesehatan terhadap pengetahuan menggosok gigi siswa SDI Raden Paku Surabaya, menunjukkan tidak ada perbedaan efektifitas hasil pendidikan kesehatan menggunakan media flipchart dan komik.

\section{SARAN}

Berdasarkan hasil dan pembahasan penelitian yang dilakukan tentang efektifitas penggunaan media flipchart dan komik dalam pendidikan kesehatan terhadap pengetahuan menggosok gigi siswa SDI Raden Paku Surabaya maka dapat diberi saran sebagai berikut :

1. Bagi SDI Raden Paku Surabaya

2. Diharapkan kepala sekolah dan guru SDI Raden Paku Surabaya dapat bekerjasama dengan petugas kesehatan untuk memanfaatkan media dalam memberikan pendidikan kesehatan gigi kepada siswa, dan kepala sekolah dan guru dapat membentuk UKGS dan kader cilik sebagai pedoman dalam menyampaikan pendidikan kesehatan gigi dan mulut.

3. Bagi Institusi Jurusan Keperawatan Gigi Surabaya

4. Diharapkan institusi jurusan keperawatan gigi Surabaya dapat menjadi sumber pengetahuan di perpustakaan Jurusan Keperawatan Gigi Surabaya agar menjadi acuan bagi peneliti selanjutnya.

\section{DAFTAR PUSTAKA}

Adipta, H., Maryaeni, M., \& Hasanah, M. (2016). Pemanfaatan Buku Cerita I Bergambar Sebagai Sumber Bacaan Siswa Sd. Jurnal Pendidikan - Teori, Penelitian, Dan Pengembangan, 1(5), 989-992. https://doi.org/10.17977/jp.v1i5.6337. Diakses 4 Oktober 2019. 
Arikunto, S. 2010.Prosedur Penelitian: Suatu Pendekatan Praktik. Yogyakarta.. Rineka Cipta.

Arsyad, Azhar (2011). Buku Media Pembelajaran, Jakarta. PT RajaGrafindo Persada.

Haq, Z. (2017). Penggunaan Komik Kesehatan Gigi Dalam Meningkatkan

Pengetahuan Dan Kepercayaan Siswa Kelas V Sdn Martopuro 01 Kecamatan Purwosari Kabupaten Pasuruan. Jurnal PROMKES, 3(2), 124. https://doi.org/10.20473/jpk.v3.i2.2015.124-133.Diakses 4 November 2019.

Kantohe, Z. R., Wowor, V. N. S., \& Gunawan, P. N. (2016). Perbandingan Efektivitas pendidikan kesehatan gigi menggunakan media video dan flip chart terhadap peningkatan pengetahuan kesehatan gigi dan mulut anak. E-GIGI, 4(2), 7-12. https://doi.org/10.35790/eg.4.2.2016.13490. 4 Desember 2019.

Kemenkes RI. (2012). Buku Panduan Pelatihan Kader Kesehatan Gigi dan Mulut di Masyarakat. Kementerian Kesehatan RI.

Kemenkes RI. 2012. Pedoman Usaha Kesehatan Gigi Sekolah (UKGS). Jakarta.

Kemenkes RI. 2018. Laporan Riset Kesehatan Dasar 2018, Surabaya.

Kesehatan, J. I., Husada, S., Sitanaya, R. I., Gigi, K., Kemenkes, P., \& Artikel, M. (2019). ARTIKEL PENELITIAN Efektivitas Flip Chart Dan Media Audiovisual tentang Karies gigi Effectiveness of Flip Charts and Audiovisual

Media about dental caries. Jiksh, $10(2)$, 63-68. https://doi.org/10.35816/jiskh.v10i2.110

Lihayati, A. S., \& Mardiana. (2019). Pengaruh Media Komik Terhadap Pengetahuan Tentang Sarapan Pada Siswa SDN Padangsari 02. Sport and Nutrition, 1(1), 12-18. https://doi.org/10.1016/j.sasoi.2013.12.010. Diakses 4 Desember 2019.

Mahirawatie, I. C. (2015). PENGEMBANGAN PROMOSI KESEHATAN DENGAN MEDIA KOMIK TERHADAP PERUBAHAN TINGKAT KEBERSIHAN GIGI DAN MULUT (STUDI DI KLINIK JURUSAN KEPERAWATAN GIGI POLTEKKES KEMENKES SURABAYA). JURNAL PENELITIAN KESEHATAN， 13(4), 234-240.

Majid, Y. A., Carera, A. M., Majid, Y. A., Carera, A. M., Studi, P., Keperawatan, I., \&Muhamadiyah, S. (2020). MEDIA KOMIK EDUKASI DAN VIDEO ANIMASI SEBAGAI MEDIA PROMOSI KESEHATAN TENTANG KARIES GIGI PADA ANAK SEKOLAH DASAR Karies gigi merupakan suatu penyakit gigi dan mulut yang paling banyak diderita. Karies gigi dapat terbentuk karena terdapat sisa makanan ya. 5, 13-20 
Nubatonis, 2017 Promosi Kesehatan Gigi Dengan Menggunakan Media Leafleat

Terhadap Pengetahuan, Sikap Dan Status Kebersihan Gigi Dan Mulut Siswa Sekolah Dasar Kota Kupang. Jurnal Poltekkes Kupang. Kupang.

Notoatmodjo S. 2012 . Promosi Kesehatan dan Perilaku Kesehatan. Ke-2. Jakarta. Rineka Cipta

Suiraoka dan supariasa. 2012, Media Pendidikan Kesehatan, Yogyakarta. Graha Ilmu.

Setyawati, N. S. (2019). Pengaruh Media Komik Terhadap Tingkat. Naskah Publikasi Polttekkes Kemenkes Yogyakarta.

Soesilaningtyas, 2018, The Effectiness Of The Story Book With Picture On Oral Health Knowledge Of Deaf Students. Unair.

Tarigan R. 2016. Karies gigi. Ed. Ke-2. ECG. Jakarta

Pengacuan daftar pustaka hanya yang telah terpublikasi. Setidaknya $80 \%$ referensi primer (jurnal artikel) minimal 10 tahun terakhir.

\section{Buku dengan Editor}

Dahar, R. W. 1996. Teori-teoriBelajar.Jakarta :Erlangga.

Campbell, A.N, Reece, B.J, dan Mictchel, G.L. 2004. Biologi Edisi 5 Jilid 3. Jakarta: Erlangga.

\section{Artikel dalam Jurnal}

McClean, et al., 2005. Molecular and Cellular Biology Animations: Development and Impact on Student Learning. Cell Biol. Educ. Vol. 4, No.2, pp. 169-179.

\section{Artikel Seminar/ Simposium}

Rustaman, N. Y,. 2002. Pandangan Biologi Terhadap Proses Berpikir dan Implikasinya Dalam Pendidikan Sains. Pidato Pengukuhan Guru Besar pada Pendidikan Biologi Universitas Pendidikan Indonesia tanggal 17 Oktober 2002. Bandung: UPI PRESS.

\section{Artikel dari Internet.}

Rogers, D. 2015. "Anas platyrhynchos" (On-line), Animal Diversity Web. Accessed August 17, $2018 \quad$ http:// animaldiversity.ummz.umich.edu/site/account/information/Anas_platyrhyncos. html. 
Home page: http://ejurnal.poltekkestasikmalaya.ac.id/index.php/jikg/index

Skripsi/Tesis/Disertasi.

Aripin, I. 2011. Penggunaan Multimedia Interaktif(MMI) untuk Meningkatkan Pemahaman Konsep, Berpikir Kritis dan Retensi pada Konsep Sistem Reproduksi di SMA.Tesis SPs UPI: Tidak diterbitkan 